\title{
Aviation Technology Life Cycle Management: Importance for Aviation Companies, Aerospace Industry Organizations and Relevant Stakeholders
}

\section{Stanislav Szabo ${ }^{1,2}$, Ivan Koblen ${ }^{3 *}$}

\footnotetext{
${ }^{1}$ Department of Air Transport, Faculty of Transportation Sciences, Czech Technical University in Prague, Prague, Czech Republic

${ }^{2}$ Faculty of Aeronautics, Technical University of Košice, Košice, Slovak Republic

${ }^{3}$ Institute of Integrated Safety, Faculty of Material Science and Technology in Trnava, Slovak University of Technology in Bratislava, Bratislava, Slovak Republic

*Corresponding author: University of Technology in Bratislava, Faculty of Material Science and Technology in Trnava, Institute of Integrated Safety, Jána Bottu 25, 91724 Trnava, Slovak Republic, Email: ivan.koblen@ @stuba.sk
}

\begin{abstract}
The paper in the introductory part underlines some aspects concerning the importance of Aviation Technology Life Cycle Management and informs on basic international standards for the processes and stages of life cycle. The second part is focused on definition and main objectives of system life cycle management. The authors subsequently inform on system life cycle stages (in general) and system life cycle processes according to ISO/IEC/IEEE 15288:2015 standard. Following the fact, that life cycle cost (LCC) is inseparable part and has direct connection to the life cycle management, the paper contains brief information regarding to LCC (cost categories, cost breakdown structure, cost estimation a.o.). Recently was issued the first part of Aviation Technology Life Cycle Management monograph (in Slovak: "Manažment životného cyklu leteckej techniky l"), written by I.Koblen and S.Szabo. Following this fact and direct relation to the topic of article it is a part of article briefly introduced the content of two parts of this monograph ( the 2nd part of monograph it has been prepared for the print). The last part of article is focused on issue concerning main assumptions and conditions for successful application of aviation technology life cycle management in aviation companies, aerospace industry organizations as well as from the relevant stakeholders side.
\end{abstract}

\section{Keywords}

Aviation technology — Life cycle cost — Life cycle management - Organization — Process — Stage — System

\section{Introduction}

The achievement of required capabilities, their sustainment and development is imperative in all areas of activities, in- cluding aviation technology. Aviation technology and systems have been used currently are becoming to be more complex. Taking these reasons into account as well as other factors and 
aspects all aviation companies, aerospace industry organizations and relevant stakeholders must improve business, management, technical and other approaches and thinking namely from whole systems life cycle. We can say that through the implementation of principles of systems life cycle management can be achieved in particular more integrated, efficient and to customer-oriented acquisition of aircraft and aviation technology and more systematically to prepare and realize processes and activities throughout individual aviation technology stages - from concept and development, through production, operation and its support to disposal of aviation technology.

The system life cycle management issue covers several international standards. Basic international standards in this area are the following standards:

- ISO/IEC/IEEE 15288:2015 Systems and software engineering - system life cycle processes,

- ISO/IEC 12207:2008 Systems and software engineering - Software life cycle processes,

- ISO/IEC TR 24748-1 Systems and software engineering - Life cycle management - Part 1: Guide for life cycle management.

These standards have a general character and establish a common framework of system and software processes and life cycle stages created by human. Processes described in these standards can be applied at any level of a system's structure hierarchy.

The system life cycle management issue and its application is highly actual also in the NATO and European Union / European Defence Agency framework particularly in the armaments, logistics, defence research and technology programmes and projects and as part of their planning and programming processes. The Alliance applied the system life cycle management principles in document "NATO Policy for Systems Life Cycle Management" [1]. Principles, processes and activities of the system life cycle management are based for the cooperation within the programmes and projects in the defence capabilities, armaments, defence research and defence industry areas (including programmes and projects focused on aviation technology and systems). This approach has strategic importance and it is known as Through Life Management approach.

\section{Definition and main objectives of system life cycle management}

According to international standard ISO/IEC/IEEE 15288:2015 the term Life Cycle is defined as an evolution of a system, product, service, project or other human-made entity from conception through retirement [2].

Life Cycle Management (LCM) is possible to characterize as a science, which knowledge on human-made system life cycle stages and processes arranging to instructions and rules for management. In practice these instructions and rules are related with concrete objects. Following this orientation we know:
- Product, system and service life cycle management,

- Project life cycle management.

The basis of Life Cycle Management creates the management of a system/product, applied throughout its life, that bases all decisions on the anticipated mission-related, political, social and economic aspects of the system Life Cycle. LCM means the systematic and controlled concept for management, evolution of both product and information concerning the product from initial idea on product creation till whole disposal and recycling.

The focus on LCM will provide an optimal adjustment of organization, its business processes and information systems to the requirements of customer and all stakeholders. LCM pays main attention on decision-making processes, which have the largest influence on the defined requirements fulfillment, system life cycle cost and assure the sufficient effectiveness. The decision making processes must be based on full reflection of system and functional requirements, economical and technical feasibility in order to produce and delivery the qualitative and effective system.

The main objectives of system/product life cycle management are as follows:

- to assure the bright and accurate requirements definition on system and their subsequent fulfillment,

- to delivery qualitative systems, which meet or exceed customer requirements in the framework of total cost and delivery time, which work effectively and include possibilities of future modernization and ensure cost effective maintenance,

- to have a total and shared view on the objectives of a project,

- to create a seamless and continuous life cycle management process throughout all system/product life cycle stages (from mission analysis, through development, production, operation and its support to system/product disposal),

- to establish a life cycle partnership between all stakeholders in the project,

- to ensure continuous technology refreshment,

- to emphasize preferring of commercially available off - the - shelf and non development solutions leading to customer needs and requirements fulfillment,

- to identify the risks in the beginning of project and to manage the risks such a way, which avoid the problems,

- to implement quality management system using the identifiable, measurable and repeatable processes,

- to establish organizational structure and project management structure with adequate authority level, which assure effective management of project throughout its life cycle,

- to identify main tasks and to define responsibility of all stakeholders, including managers and technical managers throughout system life cycle and to assure clear 


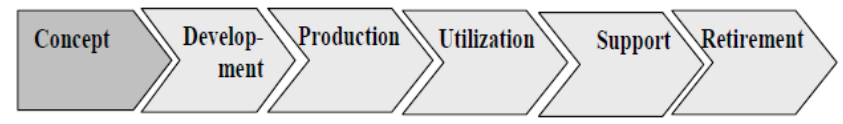

Figure 1. System life cycle stages.

responsibility for project and accountability of project management,

- to establish the adequate level of management competence for assuring of time alignment, coordination, management, review and approval of project for relevant system in order to effectively manage project throughout its life cycle,

- to inform all managers and technical managers concerning all requirements on sources and financial expenditures on system,

- to allocate competence on one control authority in the coordination, monitoring, review and approval of system function.

\section{System life cycle stages (in general)}

Life cycles vary according to the nature, purpose, use and prevailing circumstances of the system. Each stage has a distinct purpose and contribution to the whole life cycle and is considered when planning and executing the system life cycle. The stages represent the major life cycle periods associated with a system and they relate to the state of the system description or the system itself. The stages describe the major progress and achievement milestones of the system through its life cycle $[2,3]$.

They give rise to the primary decision gates of the life cycle. These decision gates are used by organizations to understand and manage the inherent uncertainties and risks associated with cost, schedule and functionally when creating or utilizing a system. According to ISO/IEC TR 24748-1 the typical system life cycle stages include (Fig. 1) [4]:

- Stage of concept,

- Stage of development

- Stage of production

- Stage of utilization (operation),

- Stage of support,

- Stage of retirement (disposal).

Technical Report ISO/IEC TR 24748-1 is a guide for the life cycle management of systems and software based on ISO/IEC/IEEE 15288 and ISO/IEC 12207. This Technical Report inter alia addresses systems concepts and life cycle concepts, models, stages, processes, process application, key points of view, adaptation and use in various domains; establishes a common framework for describing life cycles, including their individual stages, for the management of projects to provide or acquire either products or services and supports the use of the life cycle processes within an organization or a project [4].
The Concept Stage begins with initial recognition of a need or a requirement for a new system-of-interest or for the modification to an existing system-of-interest. This is an initial exploration, fact finding, and planning period, when economic, technical, strategic, and market bases are assessed through acquirer/market survey, feasibility analysis and tradeoff studies. Acquirer/user feedback to the concept is obtained.

One or more alternative concepts to meet the identified need or requirement are developed through analyses, feasibility evaluations, estimations (such as cost, schedule, market intelligence and logistics), trade-off studies, and experimental or prototype development and demonstration. The need for one or more enabling systems for development, production, utilization, support and retirement of the system-of-interest is identified and candidate solutions are included in the evaluation of alternatives in order to arrive at a balanced, life cycle solution. Typical outputs are stakeholder requirements, concepts of operation, assessment of feasibility, preliminary system requirements, outline design solutions in the form of drawings, models, prototypes, etc., and concept plans for enabling systems, including whole life cost and human resource requirements estimates and preliminary project schedules.

The Development Stage begins with sufficiently detailed technical refinement of the system requirements and the design solution and transforms these into one or more feasible products that enable a service during the Utilization Stage. The system-of-interest may be a prototype in this stage. The hardware, software and operator interfaces are specified, analyzed, designed, fabricated, integrated, tested and evaluated, as applicable, and the requirements for production, training, and support facilities are defined. This stage also ensures that the aspects of other stages (production, utilization, support, and retirement) and their enabling systems' requirements and capabilities are considered and incorporated into the design through the involvement of all interested parties. Feedback is obtained from stakeholders and those who will produce, operate, use, support, and retire the system-of-interest through such means as a series of technical or other reviews. Outputs are a system-of-interest or a prototype of the final systemof-interest, refined requirements for enabling systems or the enabling systems themselves and all documentation and cost estimates of future stages.

The Production Stage begins with the approval to produce the system-of-interest. The system-of-interest may be individually produced, assembled, integrated, and tested, as appropriate, or may be mass-produced. Planning for this stage begins in the preceding stage. Production may continue throughout the remainder of the system life cycle. During this stage, the system may undergo enhancements or redesigns, the enabling systems may need to be reconfigured and production staff re-trained in order to continue evolving a cost effective service from the stakeholder view.

It is presumed that the organization has available the budget and enabling systems that consist of production, equipment, facilities, tools, processes, procedures and competent 
human resources. These items are developed or acquired in order to be available when needed to enable production.

The Utilization Stage begins after installation and transition to use of the system. The Utilization Stage is executed to operate the product at the intended operational sites to deliver the required services with continuing operational and cost effectiveness. This stage ends when the system-of-interest is taken out of service. Planning for this stage begins in the preceding stages. This stage includes those processes related to use of the system to provide services, as well as monitoring performance and identifying, classifying and reporting of anomalies, deficiencies, and failures. During this stage the product or services can evolve giving rise to different configurations. The operator operates the different configurations and the responsible product supplier manages the status and descriptions of the various versions and configurations of the product or services in use.

The Support Stage begins with the provision of maintenance, logistics and other support for the system-of-interest's operation and use. Planning for this stage begins in the preceding stages. The Support Stage is completed with the retirement of the system-of-interest and termination of support services. This stage includes those processes related to providing services that support utilization of the system-of-interest. This stage also includes processes to use and monitor the support system itself and its services, including the identification, classification, and reporting of anomalies, deficiencies, and failures of the support system and services. During this stage the support system and services can evolve under different versions or configurations. The support organization operates the different versions or configurations and the responsible product organization manages the status and descriptions of the various versions and configurations of the support system and services in use. It is presumed that the supporting organization has available the enabling systems, which consist of facilities, equipment, tools, processes, procedures, trained support personnel, and maintenance manuals.

The Retirement Stage provides for the removal of a systemof-interest and related operational and support services. Planning for the Retirement Stage begins in the preceding stages. This stage begins when a system-of-interest is taken out of service/ reaches its end-of-service life. End-of-service life can be the result of replacement by a new system, irreparable wear, catastrophic failure, no further use to the user, or no cost effective to continue operating and supporting the system-of-interest. This stage includes those processes related to operating the system that enables retirement of the system-of-interest (the retirement enabling system) and also includes monitoring performance of that enabling system and the identification, classification, and reporting of anomalies, deficiencies, and failures of the retirement enabling system. It is presumed that the organization has access to an enabling system, which consists of facilities, tools, processes, procedures, equipment, trained personnel and, as appropriate, access to recycling, disposal or containment facilities.

\section{System life cycle processes}

The basis in the life cycle management is application of process approach. Process is defined as a set of interrelated or interacting activities that use inputs to deliver an intended result [5]. Inputs and outputs may be tangible (e.g. materials, components or equipment) or intangible (e.g. data, information or knowledge). The process approach includes establishing the organization's processes to operate as an integrated and complete system with aim to meet dedicated goals. It is needed to underline, that process approach means systematic processes identification and their management and especially interactions among relevant processes. Main aim of the process approach is to support the organization's effectiveness and efficiency in the course of goals achieving.

International standard ISO/IEC/IEEE 15288:2015 groups the activities that can be performed during the life cycle of a system into four process groups:

- Agreement Processes,

- Organizational Project-Enabling Processes,

- Technical Management Processes,

- Technical Processes.

The four process groups and the processes included in each group are depicted in Tab.1. Each of the life cycle processes within those groups is described in terms of its purpose and desired outcomes and lists activities and tasks to be performed to achieve those outcomes. The processes described in ISO/IEC/IEEE 15288:2015 are not intended to preclude or discourage the use of additional processes that organizations find useful.

The Life Cycle Cost Management Process is not a part of the processes covered by this international standard, but activities generating this process are inseparable part of each product/system life cycle.

The ISO/IEC 12207 Systems and software engineering Software life cycle processes is an international standard for software life cycle processes. It contains categorization and description of software life cycle processes. It aims to be the standard that defines all the tasks required for developing and maintaining software [6].

The ISO/IEC 12207 standard establishes a process of life cycle software, including processes and activities applied during the acquisition and configuration of the services of the system. Each Process has a set of outcomes associated with it. The standard has the main objective of supplying a common structure so that the buyers, suppliers, developers, maintainers, operators, managers and technicians involved with the software development use a common language.

This common language is established in the form of well defined processes. The structure of the standard was intended to be conceived in a flexible, modular way so as to be adaptable to the necessities of whoever uses it. Taking into account the main objective of this international standard and its common language and flexibility, the knowledge and implementation of software life cycle processes according the ISO/IEC 


\begin{tabular}{|c|c|c|c|}
\hline $\begin{array}{l}\text { Agreement } \\
\text { Processes }\end{array}$ & $\begin{array}{c}\text { Organizational } \\
\text { Project-Enabling } \\
\text { Processes } \\
\end{array}$ & $\begin{array}{c}\text { Technical } \\
\text { Management } \\
\text { Processes } \\
\end{array}$ & Technical Processes \\
\hline Acquisition Process & $\begin{array}{l}\text { Life Cycle Model } \\
\text { Management Process }\end{array}$ & Project Planning Process & $\begin{array}{l}\text { Business or Mission } \\
\text { Analysis Process }\end{array}$ \\
\hline \multirow[t]{13}{*}{ Supply Process } & $\begin{array}{l}\text { Infrastructure } \\
\text { Management Process }\end{array}$ & $\begin{array}{l}\text { Process Assessment and } \\
\text { Control Process }\end{array}$ & $\begin{array}{l}\text { Stakeholder Needs \& } \\
\text { Requirements } \\
\text { Definition Process } \\
\end{array}$ \\
\hline & $\begin{array}{l}\text { Portfolio Management } \\
\text { Process }\end{array}$ & $\begin{array}{l}\text { Decision Management } \\
\text { Process }\end{array}$ & $\begin{array}{l}\text { System Requirements } \\
\text { Definition Process }\end{array}$ \\
\hline & $\begin{array}{l}\text { Human resource } \\
\text { Management Process }\end{array}$ & Risk Management Process & $\begin{array}{l}\text { Architecture Definition } \\
\text { Process }\end{array}$ \\
\hline & $\begin{array}{l}\text { Quality Management } \\
\text { Process }\end{array}$ & $\begin{array}{l}\text { Configuration } \\
\text { Management Process }\end{array}$ & $\begin{array}{l}\text { Design Definition } \\
\text { Process }\end{array}$ \\
\hline & $\begin{array}{l}\text { Knowledge Management } \\
\text { Process }\end{array}$ & $\begin{array}{l}\text { Information Management } \\
\text { Process }\end{array}$ & $\begin{array}{l}\text { System Analysis } \\
\text { Process } \\
\end{array}$ \\
\hline & & Measurement Process & Implementation Process \\
\hline & & $\begin{array}{l}\text { Quality Assurance } \\
\text { Processy }\end{array}$ & Integration Process \\
\hline & & \multirow{6}{*}{$\begin{array}{l}\text { Life Cycle Cost } \\
\text { Management Process }\end{array}$} & Verification Process \\
\hline & & & Transition Process \\
\hline & & & Validation Process \\
\hline & & & Operation Process \\
\hline & & & Maintenance Process \\
\hline & & & Disposal Process \\
\hline
\end{tabular}

Figure 2. Life cycle processes according to international standard ISO/IEC/IEEE 15288:2015.

12207 have principal importance for aviation and aerospace organizations.

\section{Life cycle cost}

Different aviation authorities, companies, aerospace industry organizations and stakeholders in the design, development, testing , manufacturing, operation and support areas as well as users of aviation technology and systems have been placing an increasing emphasis on Life Cycle Cost (LCC) to ensure they are given proper weight in decisions during the all system life cycle stages. In English terminology the both Whole-Life Cost (WLC) and Total Ownership Cost (TOC) have been used.

Aviation companies and users acquire and operate expensive and complex aviation systems that have a service life of many decades. Taking into account these and other factors is needed more soundly based on the programme costs and to find the better balance between the programme and budget. Reflection of approach based on the application and implementation of the methods for LCC analysis/estimation, planning and control of LCC is a key factor for fulfilment of users requirements taking into account principal aspects related to products and systems: quality, performance, acquisition time and effectiveness.

There is a several means of possible LCC dividing, but we can divide the LCC into four primary cost categories [7, 8], take into account the above mentioned life cycle stages:

- Research and development (R\&D) cost:

- Concept exploration/definition phase

- Demonstration/validation phase

- Engineering/manufacturing development phase

- Production and construction cost (especially in US literature named also as investment cost)

- Operation and support (O\&S) cost (or operation \& maintenance cost) Remark: The term O\&S cost has been used in US and other terminology, term in brackets has been used in a NATO standard ALCCP-1.

- Retirement and disposal cost

Figure 3 illustrates the system (program) life cycle and shows how its various phases (stages) relate to the phases/stages of a system's life-cycle cost. The figure is intended for illustrative purposes only; actual programs may deviate from the pattern shown. 
The list of all the cost elements in each cost category would be considered in a project and organised in a Life Cycle Cost Breakdown Structure, mainly referred as a Cost Breakdown Structure (CBS). The role of the CBS in the LCC process is twofold [7]:

- it must support the overall scope of the cost estimation process,

- it must facilitate the calculation and estimation of the relevant costs.

Depending on the system, costs or spending rates can peak at any phase in the program life cycle. It is needed to underline, that majority of total life cycle cost has been composed by operation and support (O\&S) cost. From operation of the serial aviation systems it is known, that $O \& S$ cost composes approx. 50-70\% of their total life cycle cost, in the case of F-16 combat aircraft even $78 \%$ of total life cycle cost $(2 \%$ represent the R\&D and $20 \%$ the investment cost for this type of aircraft) [8].

For each Cost Item (CI), which is part of CBS, is needed to choose a suitable method and model for the cost estimating purposes. Cost estimation is defined as the process of predicting the cost of system (product) before all the stages of the system development have been executed [9]. There are many methods and models available to conduct LCC estimation ( they can be categorized in four groups: optimization, simulation, estimation and decision support methods and models). It is important to understand the applicability of each method and model has own specifics. Availability and the quality of data is a major factor in the estimator's selection of the appropriate method [7].

In order to develop a cost estimate is needed to cover the following main areas: description of activity (including the life cycle duration), history (data collection), tools (cost element structure, inflation factors), medium, documentation and of course to have appropriate technical experts. The cost estimating process is compounded from next phases: definition and planning, data collection, estimate formation, review and presentation, final document elaboration

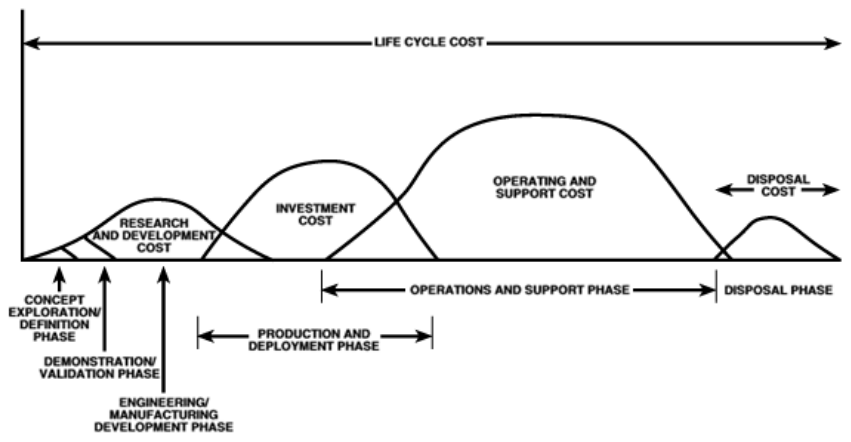

Figure 3. Illustration of Life Cycle Cost and its cost elements (cost categories) relating to stages/phases of a system life cycle [8].
A cost model is a set of mathematical and/or statistical relationship arranged in a systematic sequence to formulate a cost methodology in which outputs, namely cost estimates, are derived from inputs. Cost models can vary from a simple one - formula model to an extremely complex mode that involves hundreds or even thousands of calculations. A cost model is therefore an abstraction of reality, which can be the whole or part of a life cycle cost $[10,11]$. During the early life cycle stages most of the cost models are used to support operational analysis studies. In the later life cycle stages most models are used to support investment appraisal, logistic modelling and through life management planning. Optimization or simulation models are mainly used from the project definition stages and for optimization of logistic resources and simulation of the support system $[12,13]$.

The LCC Modelling cover especially the following issue:

- Cost Breakdown Structure (CBS)

- Product/System and Labour Breakdown Structure

- Cost Items selection

- Cost estimation

- Results presentation.

The assessment of environmental and safety risks, risk and uncertainty as attributes of LCC estimation, sensitivity analysis for identification of the key cost items issues would be the inseparable part of LCC Modelling.

LCC Models used in the framework of system life cycle are part of software tools for system LCC estimation or cost estimation of relevant life cycle stages. Among the most widespread software tools, which have been used for estimation of Aviation Technology/System LCC pertain:

- Models of PRICE Systems company (PRICE $R$ Cost Models) based on parametric methods (SW products PRICE Research, PRICE True Finding, PRICE True Planning, PRICE True Mapper)

- Selected analytical SW tools of PENNANT International Group Plc. company for support logistics analysis and decision-making processes (OmegaPS, OmegaPS Analyzer)

- SW tools of Conklin \& de Decker company (Aircraft Cos Evaluator, Aircraft Performance Comparator, Life Cycle Cost application)

\section{Selected information on Aviation Technology Life Cycle Management Monograph}

The knowledge and information concerning principles, processes and activities fall within the aviation technology life cycle management (LCM) and mainly their application in the framework of aviation technology/systems capabilities development, planning, programming and budgeting of aviation technology/systems through all life cycle stages are very important for all aviation companies, aerospace industry organization and relevant stakeholders in stages and processes 


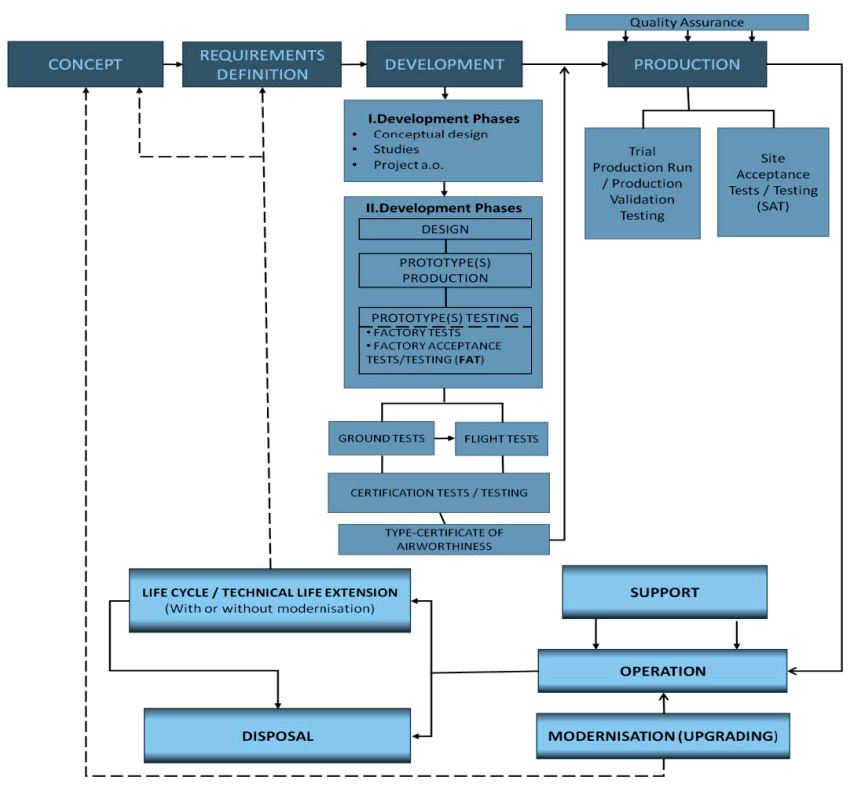

Figure 4. Aviation Technology Life Cycle Stages.

of aviation technology LCM. Take into account these factors and other aspects the Aviation Technology Life Cycle Management Monograph has been elaborated by authors I.Koblen and S.Szabo. The monograph is divided to two parts:

- Part I, which was issued (Multiprint Košice, 2016) [14]

- Part II, which has been prepared for the print [15]

\subsection{Aviation Technology Life Cycle Management - Part I}

The first part of monograph introduces information on LCM principles, definition and main objectives of system life cycle management. According to relevant international standards (ISO/IEC TR 24748-1, ISO/IEC/IEEE 15288, ISO/IEC 12207) the monograph introduced the typical system life cycle stages, system life cycle processes and software life cycle processes. Part I also includes information on life cycle cost issue. All above mentioned areas (besides the software life cycle processes) are briefly introduced in paragraphs 2,3 and 4 of this paper. Information focused on relationship of LCM to other disciplines (system engineering, system of systems engineering, TQM, supply chain management, armaments, integrated logistics support) and importance paying by relevant NATO and EU/European Defence Agency bodies and working groups to LCM issue are likewise content of this monograph - Part I.

\subsection{Aviation Technology Life Cycle Management - Part II}

The second part of monograph is focused on the key processes and information concerned the individual aviation technology stages. These stages are depicted in Fig 4. The undermentioned text content selected brief information on monographPart II chapters (which are dividing in accordance with aviation technology stages).
Concept stage emphasises the importance of aviation technology concept stage. Among other things inform on principal European Union document Flightpath 2050 (which is Europeś vision for aviation), the key European research projects in the aviation area (including the Horizont 2020, Clean Sky JTI program a.o.).

Special attention is paying to chapter Aviation Technology Definition (Requirements) Stage . It is explained the key aspects influencing to formulation of technical requirements on aviation technology. These aspects are depicted in Fig. 5.

This chapter explain in more details environmental aspects of aviation technology/systems design (emissions, noise in aviation transport) as well as requirements resulting from the principal European legislation regarding to aviation technology/systems and organizations. Basic importance in this area have the European Parliament and Commission Regulations concerning European Aviation Safety Agency (EASA) containing the implementing rules for the certification - initial airworthiness and continuing airworthiness issues (see Fig.4). The issue regarding the specifics of European common approach to military airworthiness issue (MAWA Forum, EMARs a.o.) is also described in this chapter.

The chapter focused on Aviation Technology Development Stage inform on appropriate phases of development, including prototype(s) production (inter alia digital production, new materials and additive Technologies), tests/testing of prototype(s) - ground, flight and certification tests (also in the area of jet engines), specifics of military air force technology - and necessary certifications for development and production organizations.

The chapter concerning Aviation Technology Production inter alia underlines the selected aspects of aerospace supply chain management, tests/testing during the production and installation of aviation technology and equipment, selected aspects of quality assurance (including the auditing processes and overview of international organizations involved in aviation quality (IAQG,EAQG, SAE Int., ASD).

The authors paying notable attention to Aviation Technology Operation Stage. In this regards the technical life/life

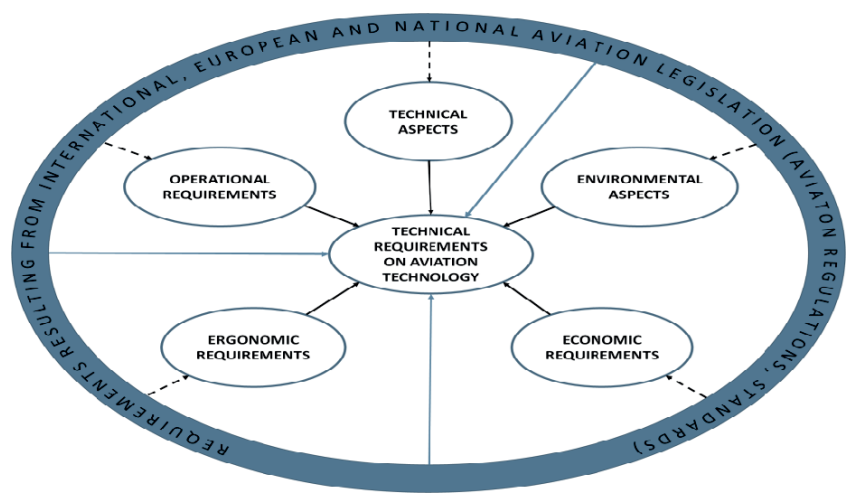

Figure 5. The key aspects (areas) influencing to formulation of technical requirements on aviation technology. 
cycle extension, modernization and upgrading of aviation technology/systems and aviation technology/systems obsolescence management issues are explained. In the framework of obsolescence management area are described the mechanisms of the aging aircraft (with emphasis on corrosion and fatigue damage problems, including aircraft widespread fatigue damage issue), approaches toward the structural design of aircraft a.o.

Very important area of aviation transport and aviation technology is Support of Aviation Technology Operation Stage. In this regard the authors inform on classification of aircraft maintenance methods, underline the importance of aviation technology diagnostics (selection of diagnostic parameters, aviation diagnostics methods, Health and Usage Monitoring System, including short description of Eurofighter Typhoon IMRS system) and selected ground support equipment.

Concerning Aviation Technology/Systems Disposal Stage the authors explains the reasons and aspects for aircraft disposal and main processes and activities in this area as well as introduce information focused on main subjects involved in ecological disposal process, aviation equipment recycling and on selected projects (PAMELA) and association in this issue (AFRA).

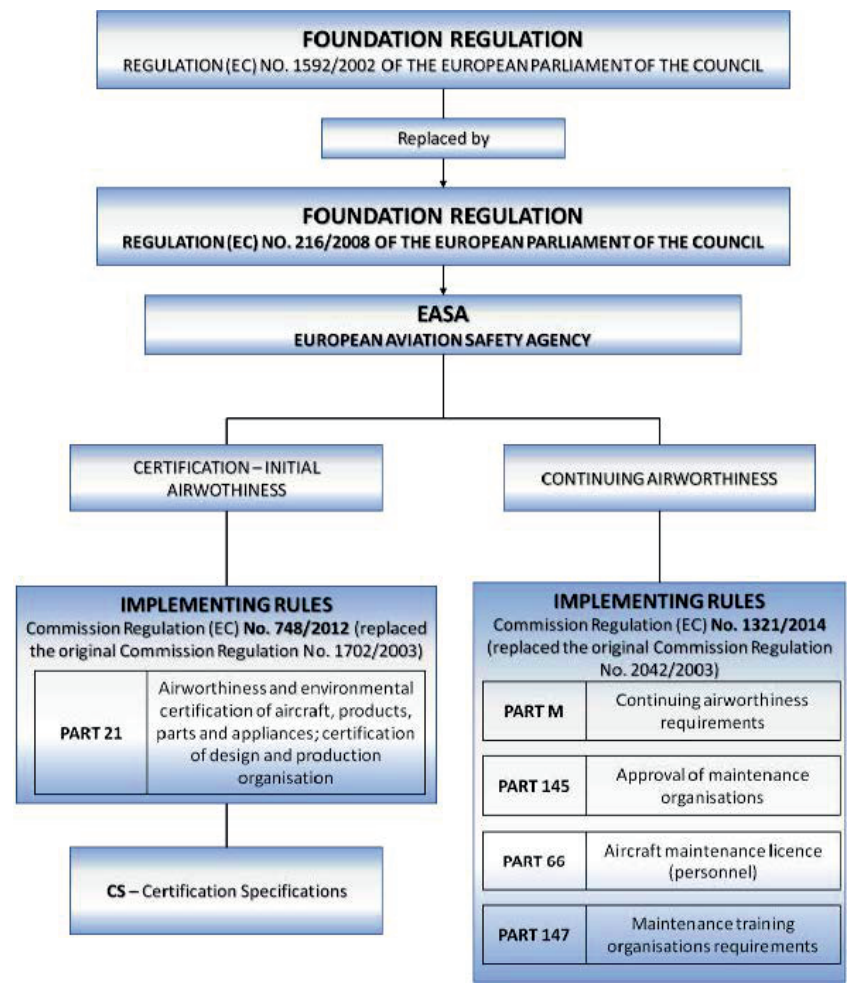

Figure 6. Overview of principal European legislation regarding to aviation technology/systems.

\section{The main assumptions and conditions for successful application of aviation technology life cycle management in organizations}

The aviation technology life cycle management and its application in the planning and implementation of programs and projects in the aviation technology/systems area is from knowing point of view very large. Take into account limited volume of article it is possible to summarize the main assumptions and conditions for successful application of aviation technology life cycle management into the management processes, planning and implementation processes within the programs and projects in aviation companies, aerospace industry organizations and relevant stakeholders into the following areas:

1. Application of principles, processes and activities of aviation technology/systems life cycle management is a key factor from the creating of effective acquisition system (realized by development, production and implementation/introduction or through procurement ways) and operation and support of aviation technology/systems as well as capabilities development in the aviation technology/systems area.

2. For the successful application of aviation technology life cycle management the holistic approach and involvement of all organization (organization means the corporate body, department - e.g. department of transport, department of defence a.o.) and organization top management is needed, as either the stakeholders management bodies involvement.

3. The conceptual, planning and programming documents would contain a clear defined and harmonized aims for the processes, activities and methods implementation from the aviation technology life cycle management point of view, including the cost estimating and assessment throughout aviation technology/system life cycle and its relevant stages. It is needed to define also activities in the key functional life cycle management elements: capabilities management (technology area and threats), asset management (availability and configuration), support management (engineering area and logistics) and commercial management (funding and contracts).

4. . Management and implementation of approaches based on aviation technology/systems life cycle mean also the particular processes integration and elimination of duplicity in decision-making processes, including the acquisition and procurement processes.

5. The application of approaches based on aviation technology/systems life cycle management represents to pay a priority attention to organization capabilities sustainment and improvement in the technology areas, i.e. in the technical processes, which must rise and to be closely connected and coordinated with agreement pro- 
cesses, organizational project-enabling processes and technical management processes. In this regard the organizations must dispose the skilled and qualified personnel and needed equipment, devices and infrastructure (including technology and testing base), which is able to carry out determined activities focused on definition of technical, operational and economic requirements (including LCC issue) and during the appropriate stages and processes of

6. In the course of application of approaches based on aviation technology/systems life cycle management in aviation programmes and projects areas is needed to apply the key processes and information recommended in international standards and to transform information from relevant documents and working groups of international institutions and organizations ( including NATOAC/327 Group on system life cycle management and European Union/EDA) and to apply the best practices in aviation technology/systems life cycle management used on the National and companies levels.

\section{Conclusion}

Implementation of practices, activities and approaches based on aviation technology/systems life cycle management in the programmes and projects in the aviation technology and systems areas and within the aviation companies, aerospace industry organizations and other organizations supplying the aviation equipments and components and providing appropriate services throughout development, production, operation, support and disposal stage of aviation technology and in the framework of relevant stakeholders is a necessary assumption from their preparedness and ability to be competitive and have capabilities to participate in the international programmes and projects in these areas [16].

The main benefit from implementation of processes and activities in the framework of aviation technology/systems life cycle management and their transformation into the organization planning processes ( achieving the approach , ThroughLife Management Planning), capability management processes and programming and budgeting processes of aviation technology/systems is possible to see in the following areas:

- Strategic area: the achievement of more unified and cohesive capabilities

- Knowledge management: knowledge are managing by central manner whereby to enable higher effectiveness in the aviation technology and equipment supplies, aviation technology/systems integration, configuration management, support management and benefits in further areas.

- Cost management: the benefit resulting from the cost taken into account, throughout all the life cycle stages (whole life cycle cost) in the planning and programming areas, inclusion LCC estimation or decisive cost items as part of tender/acquisition assessment criterions.
- Risk management: to minimize the risk already in early aviation technology life cycle stages, involvement of the users and their ability to assess the risks in relevant aviation technology stages.

\section{References}

[1] NATO. NATO Policy for Systems Life Cycle Management, No. C-M (2005) 0108, 2005. URL www . army . cz./assets/files/7284/policy.pdf. [Online].

[2] ISO/IEC/IEEE 15288:2015. Systems and software engineering - system life cycle processes, 2015.

[3] S. Szabo, I. Koblen, and Iveta Vajdová. Aviation technology life cycle stages. eXclusive e-Journal, 2015(3), 2015.

[4] ISO/IEC TR 24748-1:2016. Systems and software engineering -Life cycle management. Part 1 - Guidelines for life cycle management, 2016.

[5] STN EN ISO 9000:2016. Systémy manažérstva kvality. Základy a slovník, 2016. [In Slovak].

[6] ISO/IEC 12207:2008. Systems and software engineering - Software life cycle processes, 2008.

[7] NATO. ALCCP-1: Nato Guidance On Life Cycle Costs. NATO: Standardization Agreemens, 1 edition, 2008.

[8] USA Department of Defence. Operating and Support Cost-Estimating Guide. USA DoD: Office of the Secretary of Defence, 1992. URL http://www. dtic. $\mathrm{mil} / \mathrm{pae} /$.

[9] P. Thokala. Life cycle cost modelling as an aircraft design decision support tool. $\mathrm{PhD}$ thesis, University of Southampton, 2009.

[10] NATO. Methods and models for life cycle costing. North Atlantic Treaty Organisation, Research \& Technology Organisation, Neuilly-sur-Seine Cedex, France, 2007. ISBN 978-92-837-0072-2.

[11] I. Koblen, S. Szabo, and P. Bučka. Manažment životného cyklu obranných systémov. Vojenské reflexie, 5(3):7-28, 2010. [In Slovak].

[12] J. Gajdoš, L. Socha, and B. Mihalčová. The use of penalty functions in logistics. NAŠE MORE, Znanstveno-stručni časopis za more i pomorstvo, 61(1-2):7-10, 2014.

[13] H. Pavolová and A. Tobisová. The model of supplier quality management in a transport company. NAŠE MORE, Znanstveno-stručni časopis za more i pomorstvo, 60(5-6): 123-126, 2013. 
[14] I. Koblen, S. Szabo, and P. Bučka. Manažment životného cyklu leteckej techniky- časť I. Multiprint, Košice, Slovakia, 2016. ISBN 978-80-89551-28-6. [In Slovak].

[15] I. Koblen and S. Szabo. Manažment životného cyklu leteckej techniky- čaš II. Multiprint, Košice, Slovakia, 2017. In Press. [In Slovak].

[16] I. Koblen, S. Szabo, and P. Bučka. Obranné spôsobilosti, výskum, vyzbrojovanie a obranný priemysel v kontexte európskej spolupráce. Armed Forces Academy of general Milan Rastislav Štefánikat, Liptovský Mikuláš, Slovakia, 2017. ISBN 978-80-8040-432-1. [In Slovak]. 